\title{
The Liability of the Custodian If the Victim is Proven to Have Contributed to the Damage
}

\author{
Mohammed Ali Al-Ta'any ${ }^{1}$ \\ ${ }^{1}$ School of Law, Jadara University, Irbid, Jordan \\ Correspondence: Mohammed Ali Al-Ta'any, School of Law, Jadara University, Irbid, Jordan. Tel: 962-7-9548- \\ 0788. E-mail: m.taani@jadara.edu.jo
}

Received: July 3, 2020

doi:10.5539/jpl.v14n1p12
Accepted: October 18, $2020 \quad$ Online Published: November 25, 2020

URL: https://doi.org/10.5539/jpl.v14n1p12

\begin{abstract}
Aims: This study aims to address the custodian liability for losses caused by an object under his control, especially for the damages occurred by mechanical machines, and showing the effect of split liability on the custodian's liability especially in cases of paying compensation to the victim. On the other hand, this study discusses the custodian liability under the Jordanian law and some of the Arab laws.

Materials and methods: Following identification of the study objectives, the researcher compared the legal frames in Jordan and other surrounding countries. The researcher was able to formulate the present study.

Study findings: The legal text in Article (261) of the Jordanian Civil Code exempts the custodian in its main text from paying compensation under some conditions such as natural disaster, unavoidable accident, force majeure, an act of a third party, or act of the person suffering loss, while at the same time the Article ended with the phrase "unless otherwise stipulated by law or agreement." Which I think is unnecessary here and shall be omitted. The Jordanian legislation also neglected to clarify the types of fault that may be caused by the victim especially, if it is proved that the victim has contributed to causing the damage, the fault of the custodian, in this case, can be rebutted.

Conclusion: The Jordanian legislator did not comprehensively specify the types of the victim's fault, while the Lebanese legislator has clarified those types. Explicitly, there is no need for the part of Article (261) of the Jordanian Civil Law which says that "otherwise or agreement" because the text is clear and fulfills its intended purpose.
\end{abstract}

Keywords: custodian of things, damage, liability, fault

\section{Introduction}

Liability in law is a measure of a person's mental capacity, used in deciding the extent to which a person can be held accountable for a crime or damage (Pickard, 2015). Where custodian liability means that a person is liable for losses caused by an object under that person's control (Tahiri, 2017). It has its origins in French law (Wagner, 2012). Article 1384(1) of the French Code Civil states that a person is responsible for the damage caused by things in his custody. Some Arab legislations have generally defined the concept of damage liability, for example, the Jordanian Civil Code stated in Article (256) that "Every injury inflicted on others shall bind the perpetrator, though he is a minor, to make compensation for such injury." In point of fact, the Jordanian legislator followed the guidance of Islamic jurisprudence in this Article, which does not deny liability for the committer of the damage even if he is minor and it holds him liable for his actions (Al-Fadl, 1995.)

Iraqi Civil Code in Article (191) also holds the person who commits the damage the responsibility for his actions regardless to his status by stating that "A minor - rational or irrational - or anyone having his status who has damaged the property of a third party will be liable.....". The same conditions can be seen in the Syrian Civil Code, Article (165), The UAE Civil Code, article (300), and the Egyptian Civil Code article (164).

On the other hand, the custodian has to disprove the causal relationship between the presumed fault and the harm by proving that the damage arose out as a result of an extraneous cause such as force majeure, the act of a third party, or act of the person suffering the loss. Both the fault of the person suffering loss and the fault of a third party, neither of them is considered an extraneous cause unless it is unexpected, not possible, and unavoidable. For example, if a car hits a child walking in the street, this incident may be unavoidable, but at the same time the act of playing in the streets is expected from children, so it does not deny responsibility. 


\section{Study Objectives}

This study aims to address the custodian liability for losses caused by an object under his control, especially for the damages occurred by mechanical machines, and showing the effect of split liability on the custodian's liability especially in cases of paying compensation to the victim. On the other hand, this study discusses the custodian liability under the Jordanian law and some of the Arab laws.

\section{Methods and Approaches}

This study discusses the custodian's liability when the damage is caused by the victim's fault. The Jordanian legislator has dedicated articles $(291,292)$ of the Jordanian Civil Code to deal with the damages that result from the use of dangerous objects and machinery as it stated that "Any person who has things under his control which require special care in order to prevent their causing damage, or mechanical equipment, shall be liable for any harm done by such things or equipment, save to the extent that damage could not have been averted. The above is without prejudice to any special provisions laid down in this regard." Where the Iraqi legislator also dealt with the same issue in Article (231) Iraqi Civil Code, and the Lebanese legislator had addressed it in Article (131) of the Obligations and Contracts Law, Article (316) of the UAE Civil Code and Article (178) of The Egyptian Civil Code, which has the same subject matter but is limited to the things that need special attention and the mechanical things.

Al-Sanhouri (2005) pointed out two conditions for establishing the custodian's liability which are:

1) If a person guards something requires special care or protecting mechanical machinery.

2) The damage was occurred by an act.

Whereas, according to The Napoleonic Code, the Western jurisprudence has recognized that damage and fault are the conditions for establishing liability (Abdel-Baqi,1985). Both Arab and Western jurisprudence have agreed on exempting the custodian from holding liability and compensate the victim provided that the custodian proves the force majeure or the victim's fault. (Mustafa, 1996.)

In this research, I intend to examine the possibility of the custodian to refute his liability in one of these cases of force majeure, the act of the person suffering the loss. One the other hand, showing that the presumed evident of the fault can be disproved.

The research problem is addressed by answering these questions if a person falls on a parked car in a place designated for it. Is the owner of that car or the driver obligated to pay compensation to the person who falls on it? and if a person violates the rules of pedestrian traffic and was collided by a car, Is the driver obligated to pay him compensation? Is it acceptable to assume that its the driver's fault in all cases? Does the custodian bear all the responsibility for the things that he has? And has the risk theory replaced the theory of the presumed fault or is the theory of the supposed fault still in place, and is such a mistake viable to prove the opposite or not?

In this study, the researcher follows the descriptive approach in explaining how legislation dealt with custodian of things, and the extent of the impact of the victim's fault on the amount of compensation he deserves according to the provisions of the Jordanian Civil Code. The researcher also used the comparative and analytical approach in analyzing legal texts and explaining their compatibility with the Jordanian and comparative judicial system.

\section{Results and Discussion}

\subsection{The Legal Basis for the Liability of the Custodian of Things}

The constant development of new and advanced industries, the subsequent production of various machinery, and the production of new means of transport that seeks to attain the well-being of humanity have resulted in the possibility of the exposure to great risk that may cause harm to people, therefore, it was important to determine who bears the liability for any damage and at the same time to ensure that the owners of this new machineries must take their responsibility towards any possible harm.

Custodian's liability is a principle that has its origins in French law: responsabilité du fait des choses. Shaping the law in several Arab and Western worlds have influenced by the French Code civil. Custodian's liability means that a person is answerable in damages without fault for losses caused by an object thing under that person's control. French-style custodian's liability is codified in Art 1384(1) Code civil which provides that 'on est responsable du dommage causé pare le fait des choses que l'on a sous sa garde' (a person is responsible for the damage caused by things in his custody). The legal basis for making custodians liable for damages caused by objects of any kind was occurred as a result of some spectacular judgments by the French Cour de Cassation.

The first stage in this direction was the 'arrêt du remorquer' of 1896 (Cour de Cassation, Cass. civ. 16 June 1896, DP 1897 I,433). The boiler of a towboat had exploded and critically injured one of the employees and no fault of 
the employer could be proved. To consider the employer liable, the Cour de Cassation interpreted Art 1384(1) Code civil as an independent cause of action for liability on the basis of presumed fault. In 1930 A traffic accident in which a pedestrian had been seriously injured in a collision with a truck. The Cour de Cassation re-interpreted Art 1384 (1) Code civil and dispensed with the presumption of fault that was until then rebuttable by the defendant to escape liability. Present legal doctrine considers Art 1384(1) Code civil which stated that "as a cause of action in its own right where the responsibility of the defendant is contingent on the mere possession of the object which caused the loss.

Many jurists debated the liability of the custodian for the things under his custody and its legal basis, some jurists have adopted the theory of bearing liability "risk" and among the pioneers of this movement in France, the jurist "Josserand" and "Saleilles", who opposed the idea of the fault-based liability, which represents the traditional basis of responsibility (Abdel-Baqi,1985.) The fault was excluded as a basis for liability, as the proponents of the theory of risk found that the act that caused the damage is the basis for holding liability and that the custodian of the thing who is responsible for compensation for the damage that results from of the activity he performs, in accordance to the rule "a person is liable for the damage he caused by his fault".

Thus, the basis of liability is based on the person's actions and is not subjective or personal and is based on the person's behavior and the fault he committed (Abdel-Baqi,1985.

The next two sections will address the presumptive fault of the custodian of the thing and the inadmissibility of completely excluding the fault of the victim.

\subsection{The Presumed Fault of the Custodian of "Thing"}

Al-Sanhouri (2005) explains the basics of the fault-based liability by saying: "The fault on which the liability of the custodian was based on the failure to control what he guards. As the basic principle is that every custodian is legally obligated to control the objects under his custody, and this commitment is an obligation to achieve an end, not an obligation to do care. If the thing escapes the control of its guard, then the fault occurred and then the fault can't be rebutted. To clarify this opinion, the Egyptian Court of Cassation decided: "the responsibility of the custodian is not rebutted by proving that he did not commit any mistake and that he took the required measures to avoid any damage, however, his responsibility is rebutted if he proves that the damage was caused by force majeure, wrongfulness, or the fault of others (Al-Sanhouri, 2005.)

The idea of fault had weakened gradually until it had almost disappeared in some cases, and the idea of bearing responsibility and penalty has evolved. The risk theory is based on the principle which says as long as a person benefits from his economic activity, he must be answerable for the damages he caused to others with no need to search for his fault (Qassem, 2016.)

Jurisprudence adopted the theory of risk for two main reasons: a theoretical scientific reason and a realisticpractical reason. As for the theoretical reason, the Italian positivist school, founded by the jurist Ferri, focuses on the general objective aspect of responsibility and not its subjective aspect. As for the practical, realistic reason, it is concerned with the increasing risks of work that makes it difficult for the injured person to prove the fault of the one who caused him the damage so that he can sue a claim for compensation (Obeid, 1979.)

This is what was supported by the appeal decision No. 92 of 1993 session 9/15/1994, which stated: Likewise, the presumption of the fault of the custodian can't be rebutted, and if the custodian wants to disprove his responsibility, he must disprove the causal connection between the act and the damage caused to others, and the custodian can't deny the causal connection except in the case of force majeure, sudden accident, wrongdoing, or others' fault (Amir,2006.)

While it was opposed by the Egyptian Court of Cassation Decree No. 10429 QA session 20/2/1963 Q15 G1 p. 240, that the custodian is held liable for the damage according to the conditions that are stated in Article (178) of the Egyptian Civil Code that the damage must occur by the act of the thing which requires a positive interference of the thing in that damage, if the custodian refuted his responsibility before the court in terms of that the interference of the thing was passive and that the damage was occurred by the deceased's fault (Amir,2006)

At this point, I find that the custodian's fault can be refuted provided he proves that the intervention of the object in his custody was passive interference or he can deny his responsibility by force majeure or the act of others or the act of the person suffering a loss. For example, in the famous case of Dr. Franct, the driver of the car (not the owner) is considered the custodian who bears responsibility for the damage caused by him. After this case, the French jurisprudence considers the custodian of things is the one who has the actual power or use of the thing when the damage occurred (Abdel Baqi,1985) and that the custodian can rebut his responsibility by proving the occurrence of a wrongful act of the victim, act of others or a sudden accident. 
Article (261) of the Jordanian Civil Code, Article (165) of the Egyptian Civil Code, Article (287) of the UAE Civil Code and the Iraqi Civil Code Article (211) have considered a person who proves that the loss arose out of an extraneous cause in which he played no part such as a natural disaster, unavoidable accident, force majeure, act of a third party, or act of the person suffering loss, not bound to indemnify the injured party.

\subsection{Inadmissibility to Completely Exclude the Victim's Fault}

The provisions of the Jordanian Civil Law didn't exclude the victim's fault or the others' fault from bearing the responsibility of the damage if it is joint as stipulated in Article (265) that "If several persons are responsible for a harmful act, each of them shall be liable in proportion to his share in it, and the judge may make an order against them in equal shares or by way of joint or several liabilities." This provision was adopted also in the Syrian Civil Law in Article (170), the Egyptian Civil Law Article (169), the Iraqi Civil Code in the text of Article (217). The UAE Civil Code has stipulated the same provision in Article (291).

According to the Jordanian Civil Code Article (291), any person who has things under his control that require special care to prevent their causing damage or mechanical equipment shall be liable for any harm done by such things or equipment, save to the extent that damage could not have been averted. This provision indicates that the custodian is not liable for the damage caused by the object under his custody in some cases which are:

1) When the contractual liability is established

2) Free use of the item.

3) When the fire extended to objects that its custody does not require special care.

This provision also stipulated in the Syrian law in Article (179) and the Emirati in Article (316) and the Iraqi law in Article (231) and the Egyptian law in Article (178).

From the aforementioned, we conclude that there is a focus on the fault of the victim if any and that because it has an impact on rebutting the liability of the custodian. Thus, we find that the presumed fault of the custodian can be rebutted provided he proves that the occurred accident was due to a force majeure, sudden accident, act of others, or the act of the victim and in these cases, he will not bear liability for indemnity. In this regard, I see it is necessary to delete the part of Article (261) of the Jordanian Civil Law, which states that "unless otherwise stipulated by law or agreement." Especially since the text was clear and unambiguous and is not necessary to keep this part.

\section{The Custodian's Responsibility When the Fault of the Victim is Proven}

It is recognized that jurisprudence removes the liability of the custodian if it is proven that the victim has caused the accident. If the victim's act is the cause of the accident, the custodian is free of all liability. The most important thing in this matter is that it is unnecessary to prove the act of the victim is wrong, as the custodian's liability is spontaneously refuted when it is proven that the damage is resulted by the victim and it is the only the reason of the accident. What the court regards when filing a lawsuit of this kind is to prove that the defendant's act was the cause of the damage or that several unavoidable reasons have led to the occurrence of the damage, and there may be a joint liability if the act of the victim causes the damage. (Sioufi,1994). We conclude that there is no compensation for someone who intentionally throws himself on a car, even though the driver at the time of the accident exceeded the imposed speed (Al-Naqeeb,1999.) To explain this, the next topic discusses the conditions for considering the custodian of things liable. The second deals with the concept of the victim's fault.

\subsection{Conditions for Establishing the Liability}

The jurisprudence has concluded that the liability of the custodian is based on a presumed fault of whoever has something in his custody (Al-Sanhouri, 2005), but the judiciary in Egypt believes that responsibility for the thing is not established unless it is proven that the fault has occurred by the custodian.

Custody is possessing the actual power or control over an object intentionally and exploitably, whether this control is based on a legitimate right or not (Al-Sanhouri, 2005). Thus, if an object escapes from the possession of its custodian inadvertently, by coercion, or moving the custody of this thing to others, hence, the custodian power and possession ends. Accordingly, he does not bear any responsibility for this thing or the damage caused by it. Consequently, we find that the conditions for establishing liability are; the object must be under the effective and independent authority of its owner and that the damage was not caused by a force majeure, a sudden accident, the act of others, or the act of the victim.

This is what was supported by appeal decision No. 3410 of 69 BC session 27/6 2000 (Therefore, the presumption of the custodian's fault can be rebutted, and for the custodian to disprove his liability, he must refute the causal connection between the act and the harm caused to others" (Amir, 2006.) 


\subsection{The Concept of the Victim's Fault}

The damage to the victim may have been caused by his act, from a sudden accident, force majeure, the act of another party, or a joint fault. The law doesn't require the injured party to prove the custodian 's fault because establishing the positive responsibility for committing the act exempts the victim from proving the custodian 's fault because the occurrence of the damage proves the causal connection between him and the damage, Where in this case what is required of the custodian according to the law is to rebut the causal connection and to prove that the damage has resulted from an extraneous cause such as force majeure, the act of a third party, or act of the person suffering the loss. This is what was stated in Article (131) of the Obligation Law, and it is worth noting that proving the passive role means scientifically proving that it did not establish the causal link between the thing and the harm (Al-Awaji,1996).

The indicated fault in this research is the one that is occurred by the victim's act (plaintiff), by which the defendant (custodian) and in the virtue of the law deprives the victim of compensation, provided the victim is the only source of the damage (Al-Naqeeb, 1999), or if he was involved in the harmful accident.

The objective criterion for estimating the victim's fault should be fair and suitable to measure every behavior concerning any person who is accused of causing the damage. Therefore, it is necessary to adopt a standard that does not include personal circumstances and behaviors.

The considerations of the liability for the fault of the victim have their justification which is: the fault itself causes disturbance of stability, so it is necessary to impose a penalty to limit its future effect and in this case, it is imposing compensation.

Where the second consideration, it is not fair to grant the plaintiff full compensation while he contributed to the damage by his negligence or by providing the opportunity for damage to occur. And, it is unfair that the defendant bears all the burden of compensation while the victim committed the fault, or he was involved in it.

The third consideration: is that analyzing the causal connection in the light of the cause leads to considering the fault of the victim and the extent of his contribution to causing the damage, and accordingly, he bears fair liability for the damage he involved in (Al-Naqeeb,1999.)

The Lebanese legislator has dealt with two types of damages that may be caused by the victim, as one of them comes with its circumstance or characteristics, exempt from all liability, and it is equal to the force majeure in its effect, as it alone is the producing cause of the damage. While the second type is the joint fault. The responsibility for this act remains based on the custodian, but the compensation is reduced as the plaintiff shares responsibility with the custodian. In this context, the legislator has stipulated the principle of splitting causation. (Al-Naqeeb, 1999). And this decision also was established by the jurisprudence of the Jordanian Court of Cassation No. (4096/2013).

Likewise, if the victim erred due to his deviation from the right behavior, according to the prevailing opinion, and that his fault caused damage for others such as a person who throws himself in front of a car during its moderate course, sneaks into it without the driver's knowledge or stand on the edge of the train convoy then unexpectedly turns over and gets hurt. In these cases, this fault leads to hold him liable for the accident, because his act is like the force majeure of the driver or the train driver, who did not expect the occurrence of the accident. Therefore, the responsibility of the harmful act lies in the victim's fault which was the only reason for the accident (Khalil,1998).

\section{Conclusion}

Through the aforementioned, we conclude that the Jordanian legislator did not comprehensively specify the types of the victim's fault, while the Lebanese legislator has clarified those types. Explicitly, there is no need for the part of Article (261) of the Jordanian Civil Law which says that "otherwise or agreement" because the text is clear and fulfills its intended purpose.

The decisions of the courts in the first and second degrees did not consider that the custodian can refute his liability by proving the extraneous cause, the act of others, and the act of the person suffering the loss. Rather, in its decisions goes to consider the fault of the custodian as a presumed fault therefore he bears the responsibility for the damage. Which this is not consistent with the fact that it is a legal presumption that can be disproved in reference to the conditions specified under Article (261) of the Jordanian Civil Code, Article (165) of the Egyptian Civil Code, Article (287) of the UAE Civil Code and the Iraqi Civil Code Article (211) and Article (131) of the Lebanese Obligations and Contracts Law. Unquestionably, it is necessary to activate what has been established in jurisprudence and law and pursue until it is deemed by the decisions of the courts such as the Cassation Courts in both Jordan and Lebanon and the Court of Cassation in Egypt. It has been proven to us through this research that 
the courts of cassation in France have established decisions that led to an evolution in jurisprudence and law.

According to the provisions of a sample from Arab Civil Codes, we recognize that all of them have taken into account the joint fault of the damage in its decisions, especially in the case of compensation and its amount.

\section{Recommendations}

Through this research, the researcher concluded the following:

1) Directing the attention of the Jordanian legislator to specify the types of faults that may be committed by the victim, so some amendments must be made in part of the civil law.

2) Omitting the phrase "otherwise or agreement" from Article (261) of the Jordanian Civil Code as this part is redundant.

3) Directing the attention of the judiciary to the fact that the custodian's fault, even if it is presumed, is a legal presumption capable of proving the opposite if any of the reasons are met, such as force majeure, sudden accident, or the act of others or the act of the victim, especially since many of the rulings issued by the courts of the first and second courts violate this law.

4) The necessity for the legislator to determine the extent of the victim's contribution to the occurrence of the damage and its effect on the compensation including if the victim's fault has dramatically caused the damage, and determine the amount of the reduction of the compensation that is due to the victim's contribution.

\section{References}

Abdel-Baqi, A. (1985). Civil liability for car accidents and other dangerous things based on the guard (Unpublished thesis).

Abu Shanab, A. (2016). Legal Research on the legal basis of responsibility for doing something in Jordanian civil law and Islamic jurisprudence. Retrieved from https://www.mohamah.net/law/

Al-Awaji, M. (1996). Civil Law (2), Part 2, Civil Liability, Bahsun for Publishing, Beirut.

Al-Fadl, M. (1995). General Theory of Commitments, Part 1: Sources of Commitment. Dar Al-Thaqafa for publishing, Jordan.

Al-Naqeeb, A. (1999). The General Theory of Responsibility Arising from Transporting Things, Human Rights Publications House. Beirut.

Al-Sanhouri, A. (2005). The mediator in explaining the new civil law (1), edition 2, Dar al Nahda al Misria, Egypt.

Amir, K, Y. (2006). Civil Liability and Compensation, Alexandria Center for the books, Egypt.

Burim, T. (2017). Liability of the Custodian or Custodian Body for the Damage Caused by the Persons Totally Divested from the Ability to Act Due to Mental Disability. European Scientific Journal, 624-645.

Egyptian Civil Code of 1949.

Hanna, P. (2015). Choice, deliberation, violence: Mental capacity and criminal responsibility in personality disorder. International Journal of Law and Psychiatry, 40, 15-24. https://doi.org/10.1016/j.ijlp.2015.04.008

Iraqi Civil Code of 1951.

Jarih, K. (1998). The General Theory of Obligations, Part 1, Human Rights Publications House. Beirut.

Jordanian Civil Code no (43) of 1976 and its amendments.

Lebanese Civil Code, no (228) of 1942.

Obeid, R. (1966). Principles of the Public Section in Punitive Legislation. Dar al fejer Al Arabi.

Qassem, M. (2016). The legal basis for liability for dangerous things Before the Iraqi judiciary. Al-Rafidain Journal of Rights, 13(49).

Sioufi, G. (1994). The General Theory of Obligations and Contracts - Part Al-Halabi Publication.

Syrian Civil Code, no(84) of 1949. https://doi.org/10.2208/jscej1949.1949.84

UAE Civil Code, $\mathrm{n}(1)$ of 1987.

Wagner, G. (2011). Custodian's Liability in European Private Law. Handbook of European Private Law. Researchgate. 


\section{Copyrights}

Copyright for this article is retained by the author(s), with first publication rights granted to the journal.

This is an open-access article distributed under the terms and conditions of the Creative Commons Attribution license (http://creativecommons.org/licenses/by/4.0/). 